\title{
Molecular detection of trypanosomatids in neotropical primates in the state of Mato Grosso, Midwest, Brazil
}

\author{
Detecção molecular de tripanossomatídeos em primatas neotropicais no \\ estado de Mato Grosso, Centro-Oeste, Brasil
}

\begin{abstract}
Stéfhano Luís Cândido'; Lucas Avelino Dandolini Pavelegini²; Thábata dos Anjos Pacheco3.
Richard de Campos Pacheco ${ }^{3 *}$ (1); Victória Luiza de Barros Silva3; Thais Oliveira Morgado4;

Edson Moleta Colodel'; 'Luciano Nakazato'; Arleana do Bom Parto Ferreira de Almeida5; Valéria Dutra'
\end{abstract}

\begin{abstract}
${ }^{1}$ Laboratório de Microbiologia e Biologia Molecular Veterinária, Hospital Veterinário - HOVET, Faculdade de Medicina Veterinária FAVET, Universidade Federal de Mato Grosso - UFMT, Cuiabá, MT, Brasil

${ }^{2}$ Laboratório de Patologia Veterinária, Hospital Veterinário - HOVET, Faculdade de Medicina Veterinária - FAVET, Universidade Federal de Mato Grosso - UFMT, Cuiabá, MT, Brasil

${ }^{3}$ Laboratório de Parasitologia Veterinária e Doenças Parasitárias dos Animais Domésticos e Silvestres, Hospital Veterinário - HOVET, Faculdade de Medicina Veterinária - FAVET, Universidade Federal de Mato Grosso - UFMT, Cuiabá, MT, Brasil

${ }^{4}$ Setor de Animais Silvestres, Hospital Veterinário - HOVET, Faculdade de Medicina Veterinária - FAVET, Universidade Federal de Mato Grosso - UFMT, Cuiabá, MT, Brasil

${ }^{5}$ Laboratório de Leishmanioses, Hospital Veterinário - HOVET, Faculdade de Medicina Veterinária - FAVET, Universidade Federal de Mato Grosso - UFMT, Cuiabá, MT, Brasil
\end{abstract}

How to cite: Cândido SL, Pavelegini LAD, Pacheco TA, Pacheco RC, Silva VLB, Morgado TO, et al. Molecular detection of trypanosomatids in neotropical primates in the state of Mato Grosso, Midwest, Brazil. Braz J Vet Parasitol 2021; 30(2): e001321. https://doi.org/10.1590/S1984-29612021041

\begin{abstract}
Trypanosomatids are uniflagellate protozoa belonging to the Trypanosomatidae family. The genera Trypanosoma and Leishmania are of paramount importance as they contain species that cause serious diseases, such as Chagas disease and Leishmaniasis, respectively. The objective of the present study was to identify trypanosomatids present in the whole blood of free-living and captive neotropical primates in Mato Grosso State, Midwest Brazil. Between 2017 and 2019, 38 blood samples were collected from seven different neotropical primate species in seven cities in the state. Through molecular techniques, including polymerase chain reaction (PCR) to amplify a fragment of the kinetoplast DNA (KDNA) and 18S ribosomal RNA (18S rRNA) gene, sequencing, and phylogenetic analysis, nine Leishmania spp. [seven L. infantum and two L. (Leishmania) amazonensis] and two Trypanosoma spp. (T. minasense and $T$. rangeli) were identified. This study contributes to understanding the occurrence and epidemiology of trypanosomatids in Mato Grosso State and the importance of neotropical primates as trypanosome hosts and possible infection sources for other animals and humans. Future identification of other blood pathogens in neotropical primates will assist in disease control and prevention strategies.
\end{abstract}

Keywords: PCR, protozoan, phylogenetic analysis, zoonosis, Leishmaniasis.

\section{Resumo}

Tripanossomatídeos são protozoários uniflagelados pertencentes à família Trypanosomatidae. Os gêneros Trypanosoma e Leishmania são de suma importância por conterem espécies causadoras de doenças graves, como doença de Chagas e Leishmaniose, respectivamente. O objetivo do presente estudo foi identificar tripanossomatídeos presentes no sangue total de primatas neotropicais de vida livre e cativos no Estado de Mato Grosso, Centro-Oeste do Brasil. Entre 2017 e 2019, foram coletadas 38 amostras de sangue de sete diferentes espécies de primatas neotropicais em sete cidades do Estado. Foram identificados por meio de técnicas moleculares, incluindo reação em cadeia da polimerase (PCR), para amplificar um fragmento do DNA do cinetoplasto (kDNA) e do gene do RNA ribossômico 18S (rRNA 18S), sequenciamento e análise filogenética, nove 
Leishmania spp. [sete L. infantum e dois L. (Leishmania) amazonensis] e dois Trypanosoma spp. (T. minasense e $T$. rangeli). Este estudo contribui para o entendimento da ocorrência e epidemiologia dos tripanossomatídeos no Estado de Mato Grosso e a importância dos primatas neotropicais como hospedeiros tripanossômicos e possíveis fontes de infecção para outros animais e humanos. A identificação futura de outros patógenos do sangue em primatas neotropicais ajudará no controle de doenças e em estratégias de prevenção.

Palavras-chave: PCR, protozoário, análise filogenética, zoonoses, Leishmanioses.

Trypanosoma and Leishmania are uniflagellate protozoa belonging to the Trypanosomatidae family (Ortiz \& Solari, 2019). Some species are pathogenic to animals and humans, such as Trypanosoma cruzi and Leishmania infantum, which are responsible for Chagas disease and Visceral Leishmaniasis, respectively (Kaufer et al., 2017).

Wild animals are susceptible to infection, and as a group, neotropical primates are of great significance as they can act as reservoirs for these pathogens (Solórzano-García \& Pérez-Ponce de León, 2018). The growth of cities, deforestation, expansion of agriculture, and maintenance of wild fauna in captivity have promoted interaction between neotropical primates and humans, increasing the risk of spreading anthropozoonoses. Therefore, studying and understanding this relationship provides pertinent information within an epidemiological scope, allowing knowledge acquisition of transmission dynamics, the sentinel role of the host, and the risks of disease emergence (Aysanoa et al., 2017).

In Brazil, information regarding the potential role of primates as a reservoir of trypanosomatid infections is scarce, and diagnosis may represent a prophylactic measure for zoonoses control, especially for non-human primates because of their physiological, genetic, and geographic proximity to humans (Wolfe et al., 1998; Coimbra et al., 2020).

Therefore, the present study aimed to detect trypanosomatid infection from the whole blood of free-living and captive neotropical primates in Mato Grosso State, Midwest Brazil, using molecular techniques, including polymerase chain reaction (PCR), sequencing, and phylogenetic analysis.

Sample collection procedures were approved by the Ethics Committee on Animal Research of the Federal University of Mato Grosso (UFMT) under protocol no. 23108.015878/2019-65 and Instituto Chico Mendes de Conservação da Biodiversidade (ICMBio), permit no. 40617-1 and 42303.

Animals captured by the Environmental Agency of the State of Mato Grosso (SEMA) and Zoonosis Disease Control (CCZ) of Cuiabá municipality were admitted at the UFMT veterinary hospital between 2017 and 2019. The primates were immobilized using ketamine and midazolam according to the body weight of each animal (Cubas et al., 2014). Whole blood samples were collected from free-ranging and captive neotropical primates, stored in tubes containing ethylenediaminetetraacetic acid (EDTA), regardless of clinical signs, and sent to the Veterinary Microbiology and Molecular Biology Laboratory at the UFMT, Cuiabá, Brazil.

The samples were stored at $-80^{\circ} \mathrm{C}$ before molecular tests, and DNA extraction was then conducted using the phenol/chloroform/proteinase K method, as previously described (Sambrook \& Russell, 2001). To verify the presence of PCR inhibitors in the DNA samples and extraction success, we tested for the presence of the mammalian glyceraldehyde-3-phosphate dehydrogenase (GAPDH) gene, with the oligonucleotides GAPDHF and GAPDHR, following the method by Birkenheuer et al. (2003).

All DNA-extracted samples were screened for Leishmania by conventional PCR performed with LeishF and LeishR primers, as described by Degrave et al. (1994). Two additional PCR protocols were applied for further testing of positive samples: one using the primers RV1 and RV2, which amplify a fragment of the kinetoplast DNA (kDNA) of L. infantum (Lachaud et al., 2002), and another using LSPF and LLAR primers to amplify a region from the kDNA minicircle of Leishmania (Leishmania) amazonensis (Conter et al., 2018). For molecular identification of Trypanosoma, a fifth PCR targeting a fragment of the 18 S ribosomal RNA (18S) rRNA gene was performed as previously described (Silva et al., 2004). Amplicons previously sequenced for each Leishmania parasite [L. infantum and L. (L.) amazonensis] were used as positive controls for PCR reactions, and T. vivax was used for Trypanosoma with ultrapure water acting as a negative control.

PCR products were resolved in 1\% agarose gels stained with GelRed ${ }^{\text {TM }}$ Nucleic Acid Gel Stain (Biotium Inc., Fremont, CA, USA) and visualized using a ChemiDoc XRS system (Bio-Rad Laboratories, Hercules, CA, USA). The expected-size amplicons of Trypanosoma were purified using the Illustra GFX PCR DNA and Gel Band Purification Kit (Cytiva, Chicago, IL, USA) and prepared for sequencing using a BigDye ${ }^{\mathrm{TM}}$ kit (Applied Biosystems, Foster, CA, USA). An ABI-PRISM 3500 Genetic Analyzer (Applied Biosystems) was used for sequencing using the same primers used for 
PCR. The obtained sequences were compared with the DNA database using the BLAST ${ }^{\circ}$ algorithm (version 2.8.0) from the National Center for Biotechnology Information (NCBI, 2021) to determine the closest identities with congeneric organisms available in GenBank®.

Sequences of the V7-V8 region of the small ribosomal subunit (SSU) rRNA gene generated in this study and homolog sequences retrieved from GenBank ${ }^{\circledR}$ were used for phylogenetic analyses to characterize Trypanosoma species. A cladrogram was built based on the neighbor-joining technique with the bootstrap method with 1,000 replicates using MEGA-X (Molecular Evolutionary Genetics Analysis) version 10.1.8 (Tamura et al., 2004). GenBank ${ }^{\circledR}$ DNA sequences of Trypanosoma spp. were included for phylogenetic analysis. Leishmania species were allocated as the out-group (Figure 1).

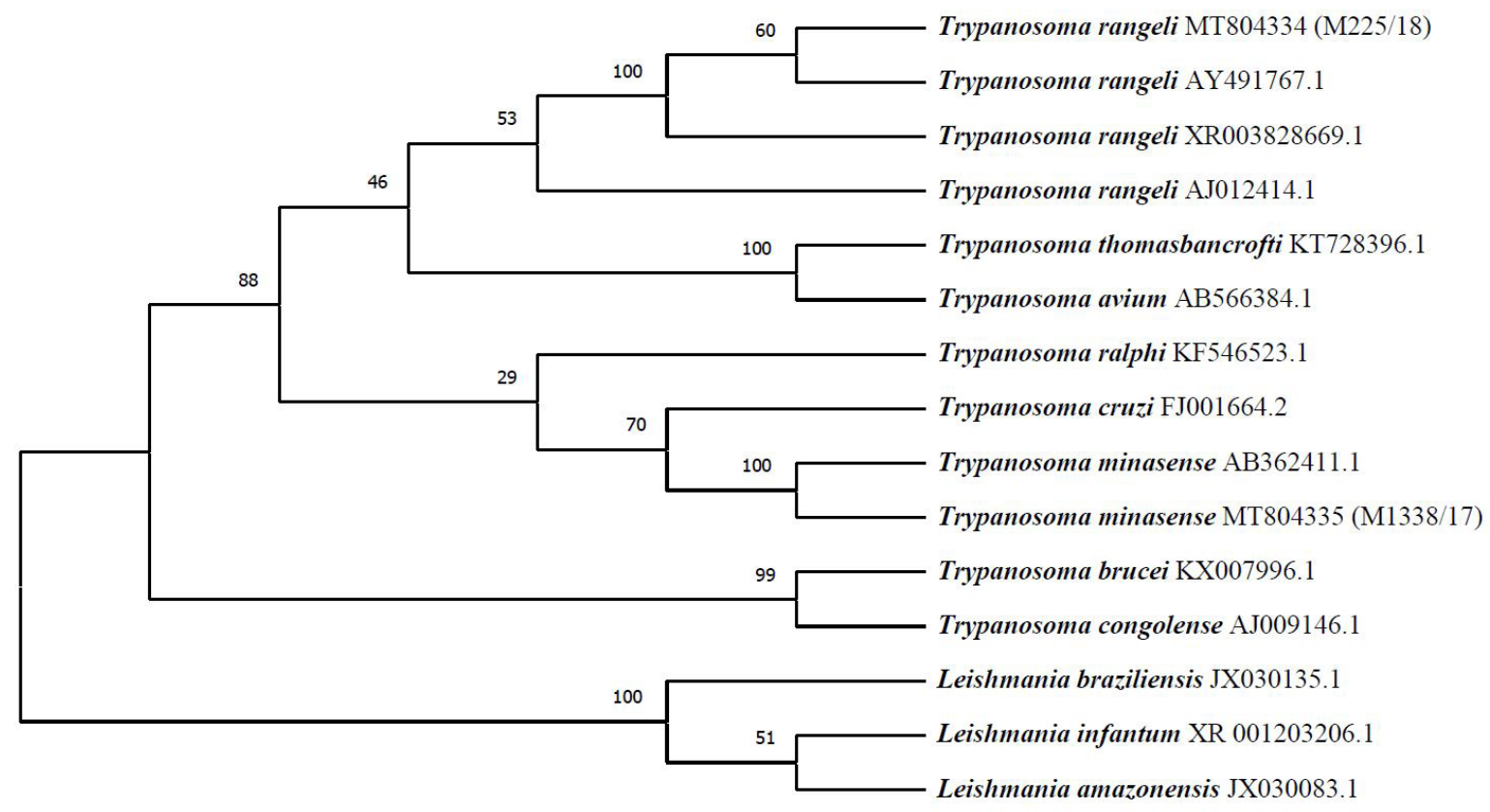

Figure 1. Cladogram of Trypanosoma spp. detected in neotropical primates, constructed using MEGA-X version 10.1.8. The cladogram was generated using the neighbor-joining technique performed with 805 base pairs of the V7-V8 region of parasite SSU rRNA genes. The initialization values are shown next to the nodes (1,000 replicates). All sequences obtained in this study are within one group, and Leishmania species were used as an out-group.

Thirty-eight neotropical primates representing Alouatta caraya, Aotus azarae, Aotus infulatus, Ateles marginatus,

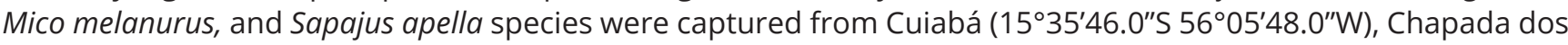

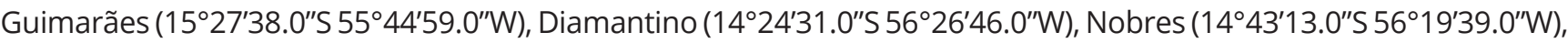

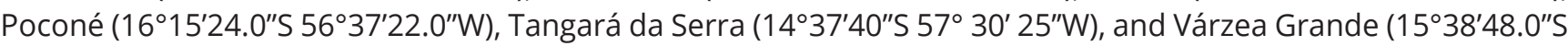
$56^{\circ} 07^{\prime} 57.0^{\prime \prime} \mathrm{W}$ ) municipalities, Mato Grosso (Figure 2).

PCR results showed that among the 38 samples evaluated, 11 (28.94\%) contained trypanosomatid DNA (Table 1); 9 of these were from free-ranging animals (23.38\%) that were positive for Leishmania spp. Among these, seven individuals (18.42\%; including three M. melanurus, three A. azarae, and one S. apella) were infected with L. infantum, whereas two animals (5.26\%; S. apella and M. melanurus) tested positive for L. (L.) amazonensis.

Furthermore, two (5.26\%) of the 18S PCR-positive samples yielded amplicons for Trypanosoma species. Partial DNA sequences generated from S. apella yielded a haplotype with $99.20 \%$ (871/878 bp) similarity to T. minasense, designated as T. minasense isolate M1338/17 (GenBank number MT804335). Further, a DNA sequence obtained from M. melanurus had a 99.36\% (938/944 bp) similarity with $T$. rangeli, designated as T. rangeli isolate M225/18 (GenBank number MT804334). The similarity of DNA and phylogenetic analysis were conclusive for accurate molecular classification. Coinfection was not observed in this study.

The best method for accurately identifying trypanosomatids is through molecular techniques, such as PCR and sequencing. They have greater specificity and differentiation capacity between species and are performed within a short time frame compared, for example, with blood cultures (Coimbra et al., 2020). 


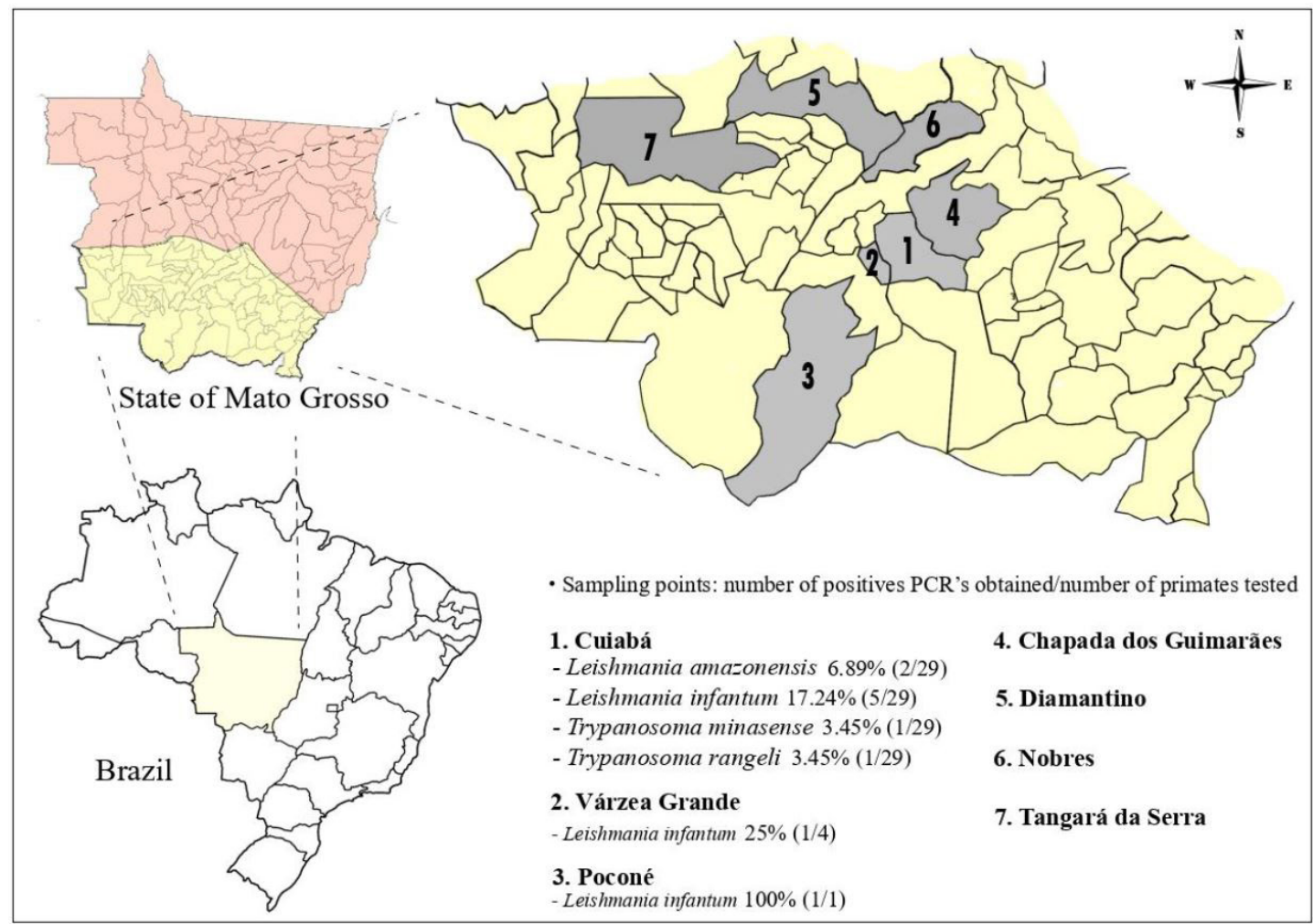

Figure 2. Map of the municipalities within the State of Mato Grosso where samples of the primates were collected for the polymerase chain reaction (PCR) with the respective infection rates (\%).

Table 1. Epidemiological data of the animals tested and their respective results ( $F=$ Female, $M=M a l e)$.

\begin{tabular}{|c|c|c|c|c|c|c|}
\hline Identification & Host & Habitat & Sex & Municipality & Trypanosoma spp. & Leishmania spp. \\
\hline M05/17 & Sapajus apella & Captive & $F$ & Cuiabá & - & - \\
\hline M08/17 & Sapajus apella & Captive & $\mathrm{F}$ & Cuiabá & - & - \\
\hline M530/17 & Sapajus apella & Free-ranging & M & Cuiabá & - & - \\
\hline M1247/17 & Sapajus apella & Captive & M & Várzea Grande & - & - \\
\hline M1249/17 & Sapajus apella & Captive & $\mathrm{F}$ & Várzea Grande & - & - \\
\hline M1313/17 & Sapajus apella & Free-ranging & M & Cuiabá & - & - \\
\hline M1328/17 & Alouatta caraya & Free-ranging & M & Cuiabá & - & - \\
\hline M1338/17 & Sapajus apella & Free-ranging & $\mathrm{F}$ & Cuiabá & T. minasense & - \\
\hline M1339/17 & Mico melanurus & Free-ranging & $\mathrm{F}$ & Cuiabá & - & - \\
\hline M2043/17 & Mico melanurus & Free-ranging & M & Cuiabá & - & - \\
\hline M35/18 & Mico melanurus & Free-ranging & $\mathrm{M}$ & Cuiabá & - & - \\
\hline M64/18 & Aotus infulatus & Free-ranging & M & Cuiabá & - & - \\
\hline M81/18 & Aotus azarae & Free-ranging & $\mathrm{M}$ & Cuiabá & - & - \\
\hline M133/18 & Aotus azarae & Free-ranging & $\mathrm{F}$ & $\begin{array}{l}\text { Chapada dos } \\
\text { Guimarães }\end{array}$ & - & - \\
\hline M180/18 & Mico melanurus & Free-ranging & M & Cuiabá & - & - \\
\hline M204/18 & Mico melanurus & Free-ranging & $\mathrm{F}$ & Cuiabá & - & - \\
\hline M225/18 & Mico melanurus & Free-ranging & $M$ & Cuiabá & T. rangeli & - \\
\hline
\end{tabular}


Table 1. Continued...

\begin{tabular}{|c|c|c|c|c|c|c|}
\hline Identification & Host & Habitat & Sex & Municipality & Trypanosoma spp. & Leishmania spp. \\
\hline M656/18 & Sapajus apella & Free-ranging & $\mathrm{F}$ & Cuiabá & - & L. amazonensis \\
\hline M742/18 & Alouatta caraya & Captive & $\mathrm{M}$ & Várzea Grande & - & - \\
\hline M897/18 & Mico melanurus & Free-ranging & $M$ & Diamantino & - & - \\
\hline M970/18 & Mico melanurus & Free-ranging & M & Cuiabá & - & L. amazonensis \\
\hline M1022/18 & Aotus azarae & Free-ranging & $\mathrm{F}$ & Cuiabá & - & L. infantum \\
\hline M1057/18 & Sapajus apella & Free-ranging & $\mathrm{M}$ & Nobres & - & - \\
\hline M1098/18 & Sapajus apella & Captive & $\mathrm{F}$ & Tangará da Serra & - & - \\
\hline M1106/18 & Sapajus apella & Captive & $\mathrm{F}$ & Cuiabá & - & - \\
\hline M1176/18 & Aotus azarae & Free-ranging & $\mathrm{F}$ & Cuiabá & - & L. infantum \\
\hline M1241/18 & Sapajus apella & Free-ranging & M & Poconé & - & L. infantum \\
\hline M522/19 & Aotus infulatus & Free-ranging & $\mathrm{F}$ & Cuiabá & - & - \\
\hline M603/19 & Alouatta caraya & Captive & $\mathrm{F}$ & Cuiabá & - & - \\
\hline M627/19 & Mico melanurus & Free-ranging & $\mathrm{F}$ & Cuiabá & - & L. infantum \\
\hline M726/19 & Aotus infulatus & Free-ranging & M & Cuiabá & - & - \\
\hline M790/19 & Mico melanurus & Free-ranging & $\mathrm{F}$ & Várzea Grande & - & L. infantum \\
\hline M1176/19 & Aotus azarae & Free-ranging & $\mathrm{F}$ & Cuiabá & - & L. infantum \\
\hline M1460/19 & Mico melanurus & Free-ranging & $\mathrm{F}$ & Cuiabá & - & L. infantum \\
\hline M1638/19 & Ateles marginatus & Captive & $\mathrm{F}$ & Cuiabá & - & - \\
\hline M1639/19 & Ateles marginatus & Captive & $\mathrm{F}$ & Cuiabá & - & - \\
\hline M1640/19 & Ateles marginatus & Captive & $\mathrm{F}$ & Cuiabá & - & - \\
\hline M1641/19 & Ateles marginatus & Captive & $\mathrm{F}$ & Cuiabá & - & - \\
\hline
\end{tabular}

Considering this bias, the results obtained for Leishmania spp. indicated a high L. infantum occurrence, accounting for $77.77 \%$ (7/9) of the species identified. This finding points to a public health concern as non-human primates may be competent in transmitting L. infantum to the invertebrate vector Lutzomyia longipalpis (Oliveira et al., 2019).

Molecular detection also was been reported for the first time with respect to $L$. infantum in three primates of the species, $A$. azarae, a species reported to be refractory to infection in a study of in vitro infection of peritoneal macrophages (Carneiro et al., 2012). This could be attributed to in vivo immune responses that have complex characteristics. Several factors, such as the nutritional status of the individual, particular immune response, and influence predisposition to clinical leishmaniasis infection; therefore, the presence of the trypanosome does not necessarily mean the animals had leishmaniasis, and the parasites may be eliminated from the animal (Serafim et al., 2010; Laurenti et al., 2014).

L. (L.) amazonensis is endemic to South America. In the current study, L. (L.) amazonensis DNA was detected by PCR in the blood of two primate species (M. melanurus and S. apella). After experimental infection, S. apella exhibited self-healing characteristics against $L$. (L.) amazonensis infection owing to components of their innate and acquired immunity with complete elimination of the disease after 150 days (Laurenti et al., 2014).

T. minasense was identified in free-living S. apella. This trypanosome is classified as non-pathogenic, specific to non-human primates, and therefore, there are no reports of human infections (Ziccardi et al., 1996). Moreover, T. minasense has been detected in Alouatta caraya in captivity in Ilha Solteira, São Paulo, Brazil (Tenório et al., 2014), and three free-living Callithrix spp. at a botanical garden in downtown Rio de Janeiro, Brazil (Coimbra et al., 2020). Even with $T$. minasense present in several Brazilian regions, the public health risk is minimal since this protozoan is considered apathogenic; however, the reported finding is of descriptive importance. 
In the present study, T. rangeli was identified in free-living M. melanurus. T. rangeli has already been detected in 72 primates of the species Saguinus bicolor (Callitrichidae) free-living in the Amazon rainforest (Silva et al., 2008). This protozoan is classified as non-pathogenic to vertebrates. However, unlike T. minasense, it has zoonotic potential (Silva et al., 2008). Moreover, detecting this parasite does not represent a public health issue because, in humans and domestic or wild reservoirs, parasitemia has a short duration and is low (Ramirez et al., 1998).

Our findings contribute to understanding the occurrence and epidemiology of diseases caused by Trypanosoma and Leishmania in Mato Grosso State, Brazil, and the importance of neotropical primates, which may play a role as hosts and possible infection sources of these protozoans for other animals and humans. Taken together, our study encourages further work to identify other pathogens in these animals, which will assist in disease control and prevention strategies.

\section{References}

Aysanoa E, Mayor P, Mendoza AP, Zariquiey CM, Morales EA, Pérez JG, et al. Molecular epidemiology of trypanosomatids and Trypanosoma cruzi in primates from Peru. EcoHealth 2017; 14(4): 732-742. http://dx.doi.org/10.1007/s10393-017-1271-8. PMid:29098492.

Birkenheuer AJ, Levy MG, Breitschwerdt EB. Development and evaluation of a seminested PCR for detection and differentiation of Babesia gibsoni (Asian Genotype) and B. canis DNA in Canine Blood Samples. J Clin Microbiol 2003; 41(9): 4172-4177. http:// dx.doi.org/10.1128/JCM.41.9.4172-4177.2003. PMid:12958243.

Carneiro LA, Laurenti MD, Campos MB, Gomes CMC, Corbett CE, Silveira FT. Susceptibility of peritoneal macrophage from different species of neotropical primates to ex vivo Leishmania (L.) infantum chagasi- infection. Rev Inst Med Trop São Paulo 2012; 54(2): 95-101. http://dx.doi.org/10.1590/S0036-46652012000200007. PMid:22499423.

Coimbra DP, Penedo DM, Silva MOM, Abreu APM, Silva CB, Verona CE, et al. Molecular and morphometric identification of Trypanosoma (Megatrypanum) minasense in blood samples of marmosets (Callithrix: Callithrichidae) from the city of Rio de Janeiro, Brazil. Parasitol Int 2020; 75: 101999. http://dx.doi.org/10.1016/j.parint.2019.101999. PMid:31669293.

Conter CC, Lonardoni MVC, Aristides SMA, Cardoso RF, Silveira TGV. New primers for the detection Leishmania species by multiplex polymerase chain reaction. Parasitol Res 2018; 117(2): 501-511. http://dx.doi.org/10.1007/s00436-017-5726-1. PMid:29280072.

Cubas ZS, Silva JCR, Catão-Dias JL. Tratado de animais selvagens: medicina veterinária. 2. ed. São Paulo: GEN/Roca; 2014.

Degrave W, Fernandes O, Campbell D, Bozza M, Lopes U. Use of molecular probes and PCR for detection and typing of Leishmania: a mini-review. Mem Inst Oswaldo Cruz 1994; 89(3): 463-469. http://dx.doi.org/10.1590/S0074-02761994000300032. PMid:7476234.

Kaufer A, Ellis J, Stark D, Barratt J. The evolution of trypanosomatid taxonomy. Parasit Vectors 2017; 10(1): 287. http://dx.doi. org/10.1186/s13071-017-2204-7. PMid:28595622.

Lachaud L, Marchergui-Hammami S, Chabbert E, Dereure J, Dedet JP, Bastien P. Comparison of six PCR methods using peripheral blood for detection of canine visceral leishmaniasis.J Clin Microbio/ 2002; 40(1):210-215. http://dx.doi.org/10.1128/JCM.40.1.210215.2002. PMid:11773118.

Laurenti MD, Passero LFD, Tomokane TY, Francesquini FC, Rocha MC, Gomes CM, et al. Dynamic of the cellular immune response at the dermal site of Leishmania (L.) amazonensis and Leishmania (V.) braziliensis infection in Sapajus apella primate. BioMed Res Int 2014; 2014: 134236. http://dx.doi.org/10.1155/2014/134236. PMid:25309902.

National Center for Biotechnology Information - NCBI. [online]. 2021 [cited 2021 Jan 05]. Available from: https://www.ncbi.nlm. nih.gov/.

Oliveira AR, Pinheiro GRG, Tinoco HP, Loyola ME, Coelho CM, Dias ES, et al. Competence of non-human primates to transmit Leishmania infantum to the invertebrate vector Lutzomyia longipalpis. PLoS Neg/ Trop Dis 2019; 13(4): e0007313. http://dx.doi. org/10.1371/journal.pntd.0007313. PMid:30995227.

Ortiz S, Solari A. Excavata-Kinetoplastea Trypanosomatidae parasites and the interaction with their hosts. Int J Trop Dis 2019; 2: 015. http://dx.doi.org/10.23937/IJTD-2017/1710015.

Ramirez LE, Machado MI, Maywald PG, Matos A, Chiari E, Silva EL. Primeira evidência de Trypanosoma rangeli no sudeste do Brasil, região endêmica para doença de Chagas. Rev Soc Bras Med Trop 1998; 31(1): 99-102. http://dx.doi.org/10.1590/S003786821998000100013. PMid:9477704.

Sambrook J, Russell DW. Molecular cloning: a laboratory manual. New York: Cold Spring Harbor Laboratory Press; 2001.

Serafim TD, Malafaia G, Silva ME, Pedrosa ML, Rezende SA. Immune response to Leishmania (Leishmania) chagasi infection is reduced in malnourished BALB/c mice. Mem Inst Oswaldo Cruz 2010; 105(6): 811-817. http://dx.doi.org/10.1590/S007402762010000600014 . PMid:20944998. 
Silva FM, Naiff RD, Marcili A, Gordo M, D'Affonseca JA No, Naiff MF, et al. Infection rates and genotypes of Trypanosoma rangeli and T. cruzi infecting free-ranging Saguinus bicolor (Callitrichidae), a critically endangered primate of the Amazon Rainforest. Acta Trop 2008; 107(2): 168-173. http://dx.doi.org/10.1016/j.actatropica.2008.05.015. PMid:18603222.

Silva FM, Noyes H, Campaner M, Junqueira ACV, Coura JR, Añez N, et al. Phylogeny, taxonomy and grouping of Trypanosoma rangeli isolates from man, triatomines and sylvatic mammals from widespread geographical origin based on SSU and ITS ribosomal sequences. Parasitology 2004; 129(5): 549-561. http://dx.doi.org/10.1017/S0031182004005931. PMid:15552400.

Solórzano-García B, Pérez-Ponce de León G. Parasites of neotropical primates: a review. Int J Primato/2018; 39(2): 155-182. http:// dx.doi.org/10.1007/s10764-018-0031-0.

Tamura K, Nei M, Kumar S. Prospects for inferring very large phylogenies by using the neighbor-joining method. Proc Natl Acad Sci USA 2004; 101(30): 11030-11035. http://dx.doi.org/10.1073/pnas.0404206101. PMid:15258291.

Tenório MS, Oliveira e Sousa L, Alves-Martin MF, Paixão MS, Rodrigues MV, Starke-Buzetti WA, et al. Molecular identification of trypanosomatids in wild animals. Vet Parasitol 2014; 203(1-2): 203-206. http://dx.doi.org/10.1016/j.vetpar.2014.02.010. PMid:24636787.

Wolfe ND, Escalante AA, Karesh WB, Kilbourn A, Spielman A, Lal AA. Wild primate populations in emerging infectious disease research: the missing link? Emerg Infect Dis 1998; 4(2): 149-158. http://dx.doi.org/10.3201/eid0402.980202. PMid:9621185.

Ziccardi M, Lourenço-de-Oliveira R, Nogueira R. The haemoculture of Trypanosoma minasense Chagas, 1908. Mem Inst Oswaldo Cruz 1996; 91(4): 501-505. http://dx.doi.org/10.1590/S0074-02761996000400019. PMid:9070411. 